\title{
The Effects of Triethylene Glycol Dimethacrylate (TEGDMA) on the Protein of Human Dental Pulp Cells
}

\author{
Ratna Farida*, Dewi Fatma*, Karina*, Tanaya S*, Pardamean RAS* \\ *Oral Biology Department, Faculty of Dentistry, Universitas Indonesia \\ Jakarta, Indonesia. \\ Email : friedakuayu@yahoo.co.id
}

\begin{abstract}
Triethylene glycol dimethacrylate (TEGDMA) is a common component of the bonding agents and resin composites used in dentistry for restorative dentistry. However, TEGDMA could be released from composite resins following incomplete polymerization and degradation processes by salivary enzymes in the mouth. Subsequently, TEGDMA is available in saliva and diffuses toward and affects the dental pulp which contains various cells, and thus may cause severe cytotoxic effects. Objectives: To determine the total protein concentration of human dental pulp cells following exposure to TEGDMA. Materials \& Methods: Dental pulp cells were isolated from the pulp of the freshly extracted teeth and cultured in DMEM for $48 \mathrm{~h}\left(37^{\circ} \mathrm{C}, 5 \% \mathrm{CO}_{2}\right)$. Then, $2 \mathrm{mM}, 4 \mathrm{mM}$ and $8 \mathrm{mM}$ TEGDMA were added to these cells and incubated for $24 \mathrm{~h}$. The total protein was measured by Bradford Protein Assay. Results: The total protein concentration of dental pulp cells after expsured to $4 \mathrm{mM}, 8 \mathrm{mM}$, and $12 \mathrm{mM}$ TEGDMA were statistically lower $(22762.27 \mu \mathrm{g} / \mathrm{ml} \pm$ $3385.87 ; 20268.44 \mu \mathrm{g} / \mathrm{ml} \pm 1701.14 ; 23706.51 \mu \mathrm{g} / \mathrm{ml} \pm 3214.52 ;$ respectively) than the control group $(24253.77 \mu \mathrm{g} / \mathrm{ml} \pm$ 3072.88). Furthermore, the total protein concentration of culture medium after exposured to $4 \mathrm{mM}, 8 \mathrm{mM}$, and $2 \mathrm{mM}$ TEGDMA, were statistically higher $(28635.85 \mu \mathrm{g} / \mathrm{ml} \pm 2373.4 ; 35288.41 \mu \mathrm{g} / \mathrm{ml} \pm 3469.48 ; 38199.79 \mu \mathrm{g} / \mathrm{ml} \pm 2752.47$; respectively) when compared with the controls $(27073.83 \mu \mathrm{g} / \mathrm{ml} \pm 2772.47)$. Conclusion: $2 \mathrm{mM}, 4 \mathrm{mM}$, and $8 \mathrm{mM}$ TEGDMA caused cytotoxicity to human dental pulp cells showed by decreasing the total protein of cells and increasing total protein of the culture medium.
\end{abstract}

Key Words: TEGDMA, dental pulp cells, cytotoxicity, total protein

Author Corresponding Address :

Department of Oral Biology, Faculty of Dentistry, Universitas Indonesia

E-mail: friedakuayu@yahoo.co.id 


\section{INTRODUCTION}

Resin-containing materials are used routinely in dental practice as direct filling materials, fissure sealing agents, bonding resins, and resin cements. Resin composites contain triethyleneglycol-dimethacrylate (TEGDMA) as a co-monomer in amounts from 15 to $25 \%$, while bonding resins contain TEGDMA in the range 30 to $55 \%{ }^{1}$ TEGDMA is included to compensate for the high viscosity of the primary resin materials and enhances bond strengths to dentin. However, it has been reported that TEGDMA monomers were released from resin composite after polymerization into the oral environment, ${ }^{2,3}$ which may induce various deleterious effects, including inflammatory reactions, cytotoxicity, mutagenesis, and apoptosis. ${ }^{4,5,6}$ Therefore, TEGDMA can be expected to enter the body via the saliva and gastrointestinal tract. Furthermore, TEGDMA may diffuse through dentin in sufficient concentrations to cause cellular damage of the pulp. ${ }^{2}$

Stanislawski et al 7,8 reported that TEGDMA induces variable cytotoxic effects on fibroblasts. Cytotoxicity is usually indicated by decreased cell proliferation, mitochondrial activity, and protein or nucleic acid synthesis. ${ }^{5}$ Here, the aim of this study was to determine the cytotoxic effects of TEGDMA on dental pulp cells by measuring the total protein of dental pulp cells and culture medium using Bradford Protein assay.

\section{MATERIALS AND METHODS}

\section{Chemicals and Reagents}

TEGDMA 3318 mM was purchased from Sigma (USA). Dulbecco's Modification of Eagle's Medium (DMEM) was obtained from GIBCO,UK. Bradford solution was purchased from Sigma (USA).

\section{Cell culture}

The use of human primary dental pulp cells conformed to an informed consent protocol reviewed and approved by an appropriate Ethical Clearance Comitee, Faculty of Dentistry, Universitas Indonesia. Fresh extracted teeth were obtained from Dental Clinic of Universitas Indonesia. They were indicated for extraction such as for orthodonic treatments. Briefly, the teeth were split, then the pulp tissue was extracted and placed in culture medium (DMEM), centrifuged, and placed in 24-well plate $\left(2 \times 10^{5}\right.$ cells/well). Cultures were then incubated in DMEM containing $10 \%$ fetal bovine serum, $1 \%$ penicillin (Gibco,UK), $1 \%$ streptomycin (Gibco,UK) and 1\% fungizone (Gibco,UK) for 2 nights at $37^{\circ} \mathrm{C}, 5 \% \mathrm{CO}_{2}$ to leave the cells grown confluently and they were used in this assay. ${ }^{9}$

\section{Exposure of dental pulp cells to TEGDMA}

The dental pulp cells were exposed to TEGDMA with concentrations of $4 \mathrm{mM}, 8 \mathrm{mM}$, and $12 \mathrm{mM}$, for 24 hours at $37^{\circ} \mathrm{C}$. They were as Treatment groups, whilst the other group of cells without any exposure of TEGDMA was called as Control group. All experiments were 
repeated 3 times, and each sample was consisted of triplicate cultures.

\section{Bradford Protein Assay}

Bradford Protein Assay was done to determine the total protein of the cells and the cultured medium. ${ }^{10}$ After treated the pulp cells with TEGDMA, $160 \mu \mathrm{l}$ of cultured medium was placed into 96-microwell plate and added $40 \mu \mathrm{l}$ Bradford solution. Whilst, the cells on the bottom of the 24-well plate were detached by trypsin EDTA, added $300 \mu \mathrm{l}$ PBS and centrifuged $3000 \mathrm{~g}$ for 10 minutes. The pellets were mixed with $1 \mathrm{ml}$ of $10 \mathrm{mM}$ HEPES and centrifuged. The pellets then mixed with PBS and $10 \%$ SDS for 5 minutes. After that, $160 \mu$ of this mixture was placed into the 96-well plate, then added with $40 \mu \mathrm{l}$ Bradford solution. After 5 minutes, the concentrations of total protein in cultured medium and the dental pulp cells were measured by microplate reader at $655 \mathrm{~nm}$. Statistical analysis was performed by One-way ANOVA, and p-values $<0.05$ were considered "significant".

\section{RESULTS}

The results of this research were shown in figure 1 and figure 2 . Figure 1 showed the concentrations of total protein in dental pulp cells in all Treatment and Control groups. The total protein concentration in dental pulp cells of $4 \mathrm{mM}$ TEGDMA Treatment group $(22762.270 \pm 3385.868)$ was significantly lower than the Controls $(24253.771 \mu \mathrm{g} / \mathrm{ml} \pm$ 3072.881). Furthermore, the total protein concentration in cells of $8 \mathrm{mM}$ TEGDMA Treatment group $(20268.442 \mu \mathrm{g} / \mathrm{ml} \pm$ 1701.143) was significantly lower compared with the Control group $(p<0,05)$. However, the total potein concentration in Treatment group of $12 \mathrm{mM}$ TEGDMA $(23706,508 \mu \mathrm{g} / \mathrm{ml} \pm$ $3214,520)$ was statistically higher that Treatment group of $8 \mathrm{mM}$ TEGDMA, but it was still lower than the Controls.

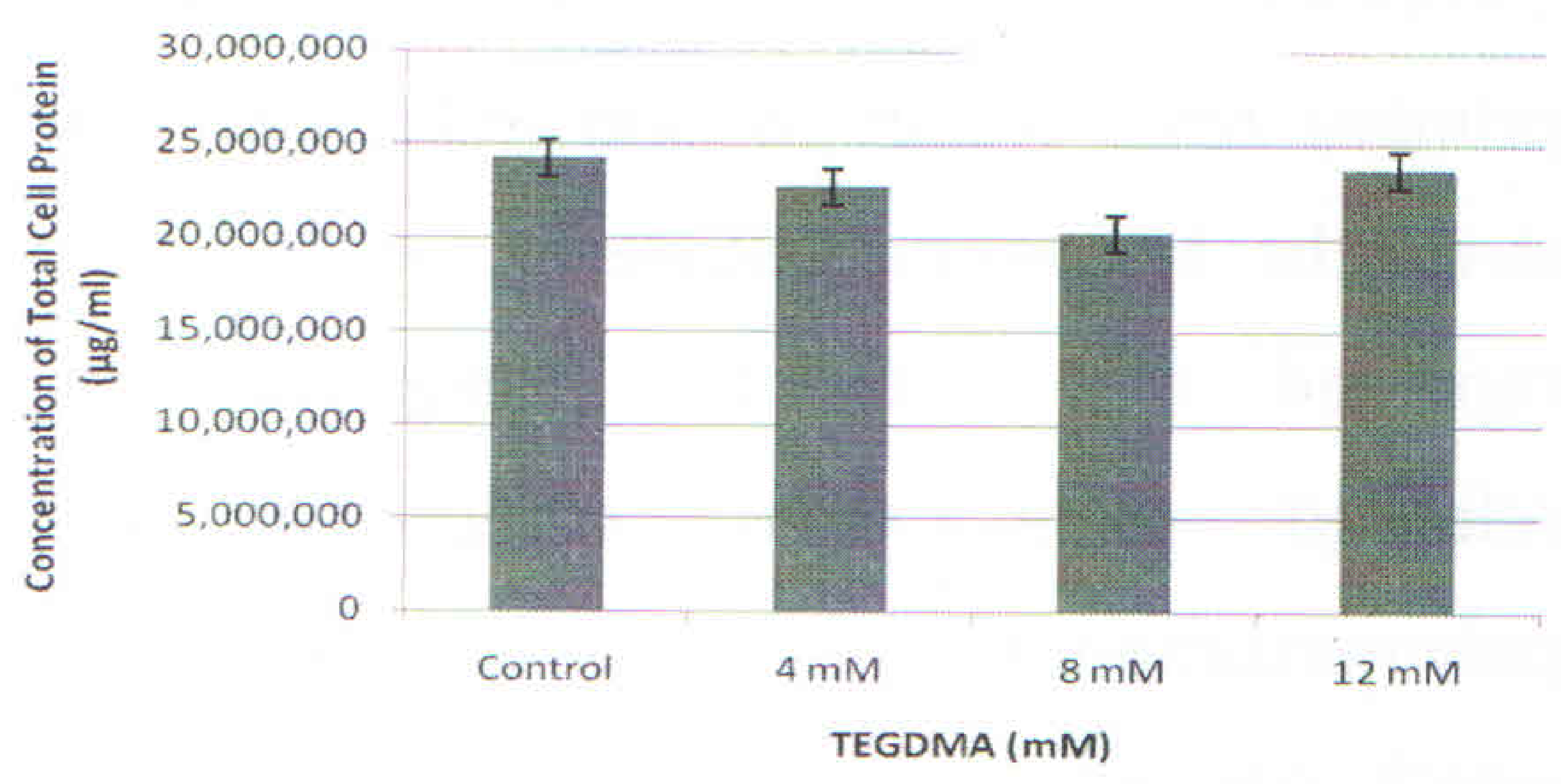

Fig.1. The concentration of total protein in dental pulp cells

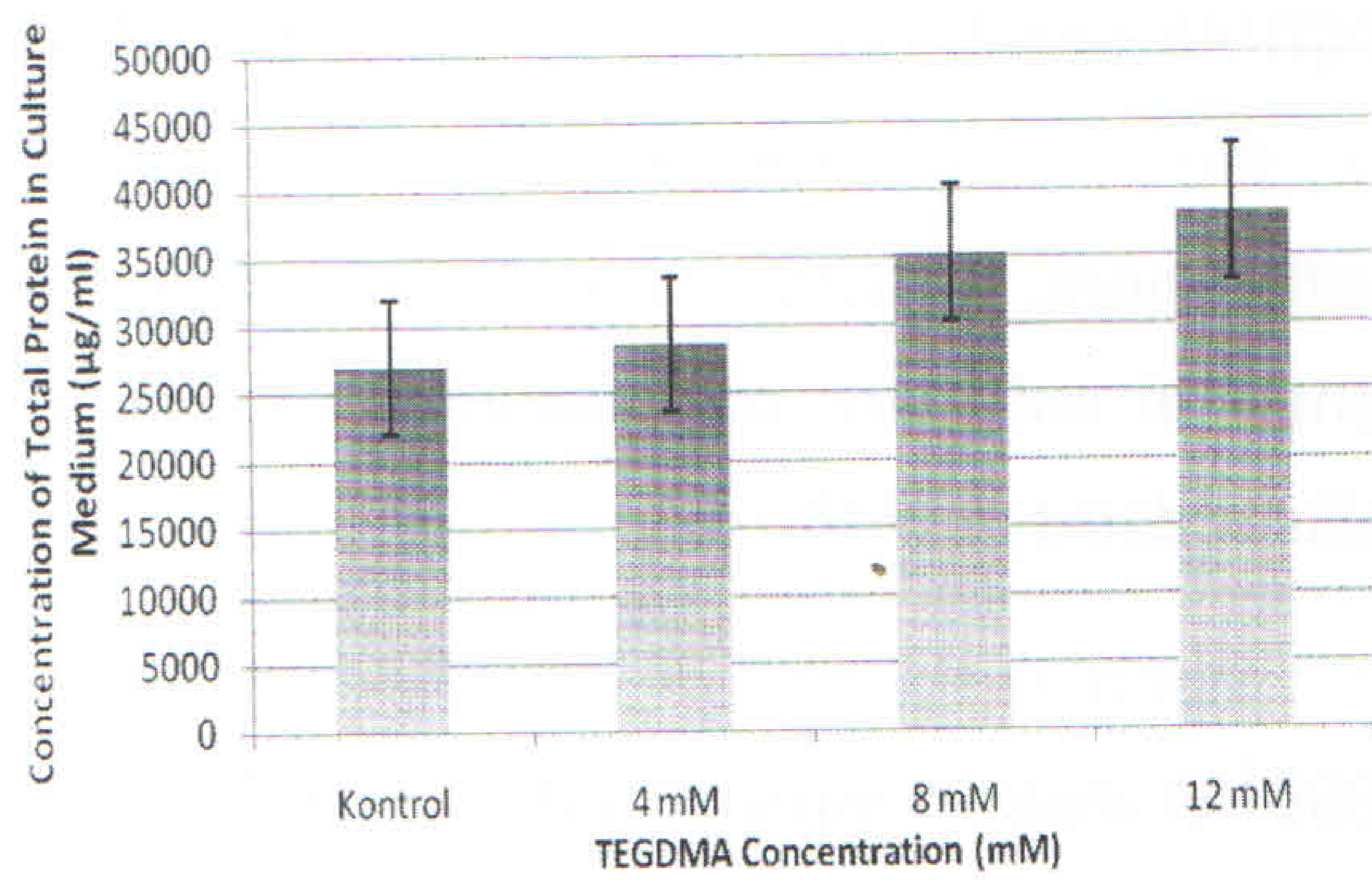

Fig. 2. The concentration of total protein in culture medium of dental pulp cells

Furthermore, the total protein concentration in culture medium of dental pulp cells in this research were shown on the Figure 2 . The Treatment group of $4 \mathrm{mM}$ TEGDMA had significantly higher total protein concentration in culture medium $\quad(28635.85 \mu \mathrm{g} / \mathrm{ml} \pm$ 2373.39) compared with the Controls 
The Effects of Triethylene Glycol Dimethacrylate (TEGDMA) on The Protein of Human Dental Pulp Cells

$(27073.83 \mu \mathrm{g} / \mathrm{ml} \pm 2772.46)$. The total protein concentration in the Treatment group of 8 $\mathrm{mM}$ TEGDMA $(35288.41 \mu \mathrm{g} / \mathrm{ml} \pm 3469.47)$ was statistically increased compared with the Control group and Treatment group of $4 \mathrm{~mm}$ TEGDMA $(p<0.05)$. The total protein concentration in culture medium of $12 \mathrm{mM}$ Treatment group $(38199.79 \mu \mathrm{g} / \mathrm{ml} \pm 2752.47)$ was statistically increased when compared with the Control group and $4 \mathrm{mM}$ Treatment group $(p<0.05)$. However, it was not statistically different when compared with the $8 \mathrm{mM}$ Treatment group.

\section{DISCUSSION}

The results from this study showed that the total protein concentration of the dental pulp cells after treated with $4 \mathrm{mM}, 8$ $\mathrm{mM}$, and $12 \mathrm{mM}$ TEGDMA were lower compared with the controls without TEGDMA treatment. Whilst, the total protein of the culture medium were higher after exposured to TEGDMA than the controls. These results suggested that TEGDMA had cytotoxic effects on dental pulp cells. Moharamzadeh (2007) reported that TEGDMA had cytotoxic effect on human gingival fibroblast and keratinocytes. ${ }^{11}$ The previous study revealed that TEGDMA was cytotoxic in various types of immortal and primary cells. ${ }^{5}$ Furthermore, Spagnuolo et al, ${ }^{12}$ reported that TEGDMA could induce apoptosis in primary human pulp cells. Decreasing of the total protein in dental pulp cells after exposured to TEGDMA was estimated as reflection of death or necrotic cells. This results support some researches which reported that decreasing protein synthesis and adenosine triphosphate content could be as a good measurement and could become a reliable indicator of cell viability, and it could determine the toxicity. ${ }^{13}$ Furthermore, other researchers also stated that toxicity could be measured from the decrease of cell growth and cell viability as result of protein synthesis inhibition. ${ }^{14}$

Janke et $a l^{6}$ reported that TEGDMA at 5 and $7.5 \mathrm{mM}$ could inhibit proliferation of human gingival fibroblast after 24 hours, whilst our investigation showed that $4 \mathrm{mM}, 8 \mathrm{mM}$, and $12 \mathrm{mM}$ inhibited proliferation of primary human dental pulp cells after 24 hours. Before that, it has been reported that TEGDMA inhibited human fibroblast and keratinocyte cell proliferations in concentration $0,25 \mathrm{mM}^{15}$

The total protein concentration of the dental pulp cells after treated with $12 \mathrm{mM}$ TEGDMA was higher than the treatment groups of $4 \mathrm{mM}$ and $8 \mathrm{mM}$ TEGDMA, eventhough it was still lower than the control. There was presence of cytokines (IL-8 and TNFa) as defense or repair mechanisms of inflammation, which could be used as indicator of cellular response to toxic materials. ${ }^{13}$ Therefore, the increased total protein concentration of $12 \mathrm{mM}$ TEGDMA group might reflect the protein of cytokines. However, it needs further investigations.

Furthermore, this study showed that the higher total protein in culture medium of all the treatment groups when compared with the control might indicate the presence of protein products of death or necrotic dental 
pulp cells and the protein released from alive cell as a response to toxic material (TEGDMA). The release of LDH (Lactate dehydrogenase) could also be used as an indicator of cell permeability due to cytotoxic or death cell. ${ }^{13}$ LDH attendance reflects the severe cells injured, cell death and decline of the integrity of cell membranes. LDH concentration will be increased when a tissue is injured. If the cell membrane loss the integrity, LDH in cytoplasma will come out into the culture medium. Previous research reported that there was a release of $\mathrm{LDH}$ into the culture medium following the disruption of the cell membrane integrity due to necrotic of cells. Thus, increasing of the LDH concentration could be measured in the culture medium of cell culture. ${ }^{16}$

\section{CONCLUSION}

TEGDMA had cytotoxic effects on dental pulp cells as it was shown by decreased total protein concentration of the dental pulp cells and increased total protein concentration in culture medium of dental pulp cells (in vitro). Consequently, it should be the aim of future studies to replace TEGDMA with more biocompatible diluent monomers.

\section{ACKNOWLEDGMENT}

The authors thank Universitas Indonesia (DRPM) for supporting the grant of this project.

\section{REFERENCES}

1. Nakabayashi N, Takarada K. Effect of HEMA on Bonding to Dentine. Dent Mater 1992; 8: 125130.

2. Hume WR \& Gerzina TM. Bioavailability of Components of Resin-Based Materials which are Applied to Teeth. Crit Rev Oral Biol Med 1996;7(2):172-179.

3. Spahl W, Budzikiewicz H, Geurtsen W. Determination of Leachable Components from Four Commercial Dental Composites by Gas and Liquid Chromatography/Mass Spectrometry. J Dent 1998; 26:137-145.

4. Schweikl H, Schmalz G. Triethylene Glycol Dimethacrylate Induces Large Deletions in the hprt Gene of V79 Cells. Mutat Res 1999; 438: 71-78.

5. Geurtsen W. Biocompatibility of ResinModified Filling Materials. Crit Rev Oral Biol Med 2000; 11: 333-355.

6. Janke V, von Neuhoff N, Schlegelberger B, Leyhausen G, Geurtsen W. TEGDMA Causes Apoptosis in Primary Human Gingival Fibroblasts. J Dent Res 2003; 82(10):814-818.

7. Stanislawski L, Daniau X, Lautie A, Goldberg M. Factors Responsible for Pulp Cell Cytotoxicity Induced by Resin-Modified Glass lonomer Cements. J Biomed Mater Res (Apll Biomater) 1999; 48:277-288.

8. Stanislawski L, Lefeuvre M, Bourd K, SoheiliMajd E, Goldberg M, Perianin A. TEGDMA Induced Toxicity in Human Fibroblasts is Associated with Early and Drastic Glutathione Depletion with Subsequent Production of Oxygen Reactive Species. J Biomed Mater Res 2003; 66(A): 476-482.

9. Freshney RI. Culture of Animal Cells. A Manual of Basic Technique. $4^{\text {th }}$ ed. New York: WilleyLiss, 2000: 157-8. 
10. BIO-RAD. Bio-Rad Protein Assay Manual Book. USA, 1993:7

11. Moharamzadech K, Van Noort R, Brook IM, Scutt AM. Cytotoxicity of Resin Monomers on Human Gingival Fibroblastand HaCat Keratinocytes. Dental Materials 2007; 23: 40-44.

12. Spagnuolo G, Galler K, et al Inhibition of Phosphatidylinositol 3-Kinase Amplifies TEGDMA-Induced Apoptosis in Primary Human Pulp Cells. J Dent Res 2004; 83(9):703-707.

13. Nikula KJ, Finch GL, Westhouse RA, Seagrave J, Mauderly JL. Progress in Understanding the Toxicity of Gasoline and Diesel Engine Exhaust Emissions. USA: SAE International 1999; 2-3.
14. Limsuwun K, \& Jones PG. Spermidine Acetyltransferase is Required to Prevent Spermidine Toxicity at Low Temperatures in Escherichia coli. Georgia: J of Bacteriology 2000; 182(19): 5373-5380.

15. Theilig C, Tegtmeier Y, Leyhausen G, Geurtsen W. Effects of BisGMA and TEGDMA upon Proliferation, Migration, and Tenascin Expression of Human Fibroblasts and Keratinocytes. J Biomed Mater Res 2000; 53; 632-639.

16. Sauvant $\mathrm{C}$, Holzinger $\mathrm{H}$, and Gekle M. Proximal Tubular Toxicity of Ochratoxin A is Amplified by Simultaneous Inhibition of the Extracellular Signal-Regulated Kinases 1/2. JPET 2005; 313: 234-241. 